Int. J. Environ. Res. Public Health 2007, 4(2), 84-92

International Journal of

Environmental Research and Public Health

ISSN 1661-7827

www.ijerph.org

(C) 2007 by MDPI

\title{
Post-Katrina Fecal Contamination in Violet Marsh near New Orleans
}

\author{
John S. Furey ${ }^{1 *}$, Herbert Fredrickson ${ }^{1}$, Chris Foote $^{2}$, and Margaret Richmond ${ }^{2}$ \\ ${ }^{1}$ Environmental Laboratory, U.S. Army Engineering Research and Development Center, 3909 Halls Ferry Road, Vicksburg, \\ Mississippi 39180-6199, USA \\ ${ }^{2}$ SpecPro, Inc., U.S. Army ERDC, 3909 Halls Ferry Road, Vicksburg, Mississippi 39180-6199, USA \\ *Correspondence to Dr. John S. Furey; Email: john.s.furey@erdc.usace.army.mil
}

Received: 10 January 2007/ Accepted: 30 April 2007/ Published: 30 June 2007

\begin{abstract}
Fecal material entrained in New Orleans flood waters was pumped into the local environment. Violet Marsh received water pumped from St. Bernard Parish and the Lower Ninth Ward. Sediment core samples were collected from canals conducting water from these areas to pump stations and from locations within Violet Marsh. Viable indicator bacteria and fecal sterols were used to assess the levels of fecal material in sediment deposited after the levee failures and deeper sediments deposited before. Most of the cores had fecal coliform levels that exceed the biosolids criterion. All of the cores had fecal sterols that exceeded the suggested environmental quality criterion. Our data show both a long history of fecal contamination in Violet Marsh and an increase in fecal loading corresponding to the failure of the levee system. The work was performed as part of the Interagency Performance Evaluation Task Force investigation into the consequences of the failures of the New Orleans levee system.
\end{abstract}

Keywords: Fecal contamination, coliforms, fecal sterols, Katrina

\section{Introduction}

Multiple failures of the levee system protection for the City of New Orleans in the aftermath of Hurricanes Katrina and Rita in August 2005 led to the flooding of the metropolitan area. The floodwaters and sediments contained dissolved and entrained chemical and microbial contaminants $[1,2,3]$. Subsequent pumping of floodwater from the city to the adjacent environment and the removal of sediment, sediment-coated debris and sediment dust aerosols are potential mechanisms to distribute these contaminants to the local environment. The United States Army Corps of Engineers created and led the Interagency Performance Evaluation Task Force (IPET) shortly after the flooding by hurricanes Katrina and Rita to evaluate the performance of the New Orleans and Southeast Louisiana hurricane protection system and the consequences of the system failure. As part of the IPET investigation of the environmental consequences of the failure of the levee system, the U.S. Army Engineer Research and Development Center (ERDC) analyzed the distribution of fecal contamination in the New Orleans environs during and after the flooding [4].

Methods to assess the quality of surface waters and sediments with respect to fecal contamination and Federal laws regulating these are in a state of flux. Prior to 1986 the U.S. Environmental Protection Agency (EPA) recommended the use of fecal coliform measurements as a water quality indicator to help prevent bathers from contracting gastrointestinal illness from recreational waters. These bacteria often did not cause illness directly, but demonstrated characteristics that made them useful as indicators of the presence of microorganisms that did cause illnesses. In 1986 EPA published "Ambient Water Quality Criteria for Bacteria" where they revised their recommendations of indicator bacteria. In this document EPA recommended the use of Escherichia coli as an indicator in fresh water and enterococci for both fresh and marine recreational waters. These revisions were based on epidemiological studies conducted by EPA which evaluated the use of several indicator microorganisms. Accidental ingestion of recreational water was the most prevalent exposure pathway. The most common bacterial infections contracted in this way included cholera, salmonellosis, shigellosis, and gastroenteritis. Common viral infections included infectious hepatitis, gastroenteritis, and intestinal disease caused by enterovirus. Protozoan infections included cryptosporidiosis, amoebic dysentery, and giardiasis.

Many federal, states, local and tribal organizations were slow to adopt EPA's 1986 guidance so EPA published "Draft Implementation Guidance for Ambient Water 
Quality Criteria for Bacteria" in 2002 to assist these organizations in implementing the 1986 recommendations [5]. The amendment to the Clean Water Act known as the Beaches Environment Assessment and Coastal Health $(\mathrm{BEACH})$ Act required coastal and Great Lakes states to have adopted EPArecommended water quality criteria by April 2004. The National Academy of Science's National Research Council recommended that the current use of indicator microorganisms be supplemented with the use of a tool box of microbiological, molecular biology and analytical chemistry techniques to better enable the protection of public health as mandated by the Clean Water Act and the Safe Drinking Water Act [6]. Regulatory criteria are expected to transition from earlier indicator-based measurement to more direct and defensible criteria. This shift is reflected in the EPA document "Standardized Analytical Methods for use During Homeland Security Events" [7] where microbial indicators are used in the early Triage and Screening stages of a response, and methods that can provide more quantitative information with respect to microbial risk assessment [8] are to be used in the Determination stage of the response.

In many circumstances indicator microorganisms are not suitable for determining fecal pollution. The use of fecal coliform as indicators in tropical waters was shown to be particularly problematic because some indicators may grow in such waters [9]. Studies of runoff from New Orleans into Lake Pontchartrain have shown that many indicator bacteria are associated with particles in the water column and quickly settle to the sediment where re-suspension of the shallow waters serves as a secondary source [10]. Logistical constraints are imposed by the fact that samples cannot be stored for long periods of time before culture and analysis. Live bacterial indicators do not persist over long periods of time in the environment so it is not possible to reconstruct historic records of previous impact using this approach. Because humans as well as many animals produce fecal bacteria markers and contribute them to the environment, it can be difficult to distinguish different sources of environmental fecal contamination using these markers.
Biochemical markers such as fecal sterols offer important advantages in selected applications. The average human excretes $0.2-1.0 \mathrm{~g}$ coprostanol per day [11]. Coprostanol comprises 4-60 percent of excreted fecal sterols and averages $3.43 \mathrm{mg} / \mathrm{gram}$ dry weight of feces [12]. Coprostanol is produced from the hydrogenation of cholesterol by bacteria in the digestive system $[13,14]$. In aerobic water columns, coprostanol is microbially degraded and half-lives of $<10$ days at $20^{\circ} \mathrm{C}$ have been reported [15]. However, coprostanol, like other fecal sterols, is hydrophobic and associated with particulate matter in sewage and water columns [16]. Coprostanol is readily incorporated into bottom sediments, where it has been shown to persist under anaerobic conditions without significant degradation for over 450 days at $15^{\circ} \mathrm{C}$ [17]. Coprostanol can serve as a useful biochemical marker for determining current and long term inputs of fecal matter to aquatic systems [18]. Based on surveys of rivers in the United States and Canada, environmental scientists have recommended three different environmental quality criteria for coprostanol; $40 \mathrm{ppb}$ (1.0 nmol/gdw [19]), $20 \mathrm{ppb}(0.52$ $\mathrm{nmol} / \mathrm{gdw}$ [14]), and $0.5 \mathrm{ppb}(0.13 \mathrm{nmol} / \mathrm{gdw}$ [20]).

The same GC/MS analysis used to determine levels of coprostanol can produce data on other fecal sterols and nonfecal sterols. The resulting sterol profile can provide additional useful information on the nature of the fecal pollution [21]. Ratios of coprostanol to cholesterol that are greater than one have been used as an indicator of fecal contamination in aquatic systems. Figure 1 illustrates the formation processes and transformations of several fecal sterols. The formation of epicoprostanol is favored in sewage treatment plants and the ratio of epicoprostanol to coprostanol has been suggested for use as an indicator of input of treated sewage relative to untreated sewage. Although coprostanol is directly formed in the human gut by the bacterial reduction of cholesterol, it can also be formed under environmental conditions in a multi-step process where cholestenone is an intermediate. The $5 \beta /(5 \beta+5 \alpha)$ cholestan-3-one ratio has been recommended for use in highly productive aquatic systems with relatively low levels of coprostanol [22].

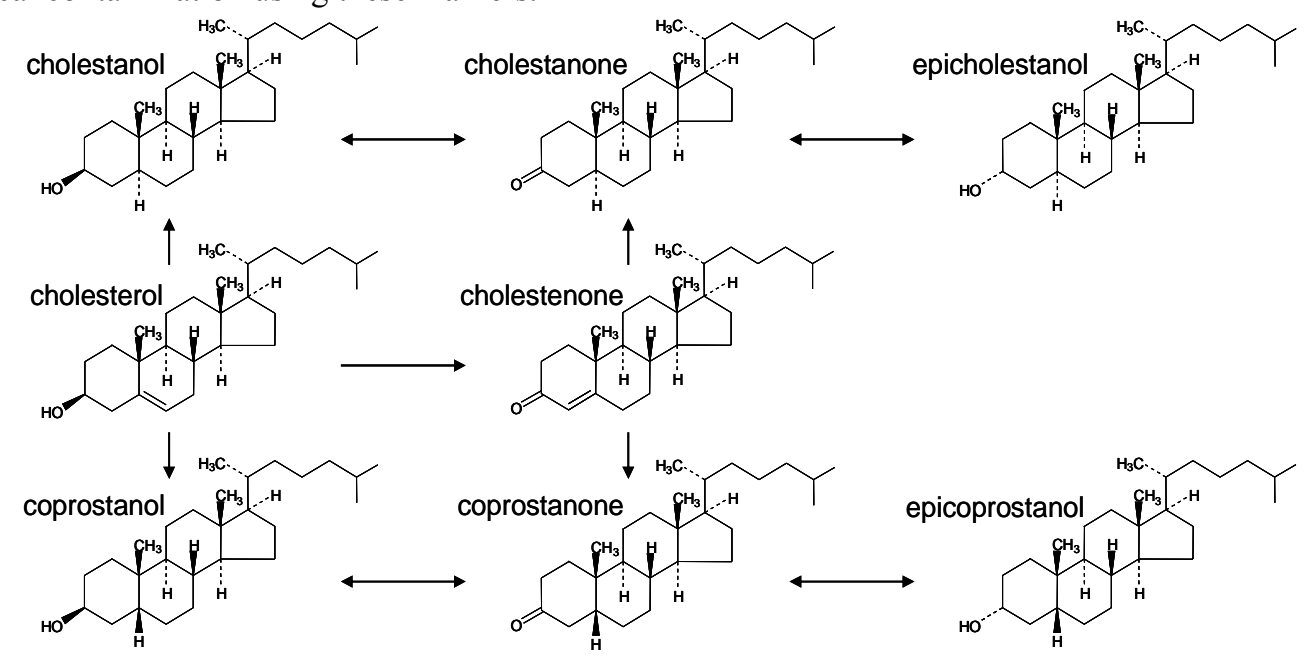

Figure 1: Structures and environmental transformation pathways of fecal sterols. 
Due to the strategy used to pump out the flooded city and the hydraulic flows resulting from this operation and the levee systems, the flooded area of New Orleans was divided into three separate drainage areas or polders: New Orleans proper, New Orleans East, and St. Bernard Parish and the Lower Ninth Ward (Fig. 2). The normal operating pumps and the emergency pumps that pumped out flooded New Orleans proper and New Orleans East drain into Lake Pontchartrain. Violet Marsh received the pumping from St. Bernard Parish and the Lower Ninth Ward of New Orleans, the main urbanized areas east of the Inner Harbor Navigation Canal and south of the Intracoastal Waterway. The floodwater and sediment in all three polders frequently exceeded state and Federal fecal standards, and no trend (increasing or decreasing contamination) was evident with time as the water was pumped out [4]. Health advisories were issued during the flood, mostly because of sewage in the floodwaters, and effects were seen. Of the 10,047 New Orleans patient visits during and immediately after the flooding for which information was available to the Centers for Disease Control and Prevention, the most common were attributable to contact with fecal contamination in the floodwaters and sediments [23].

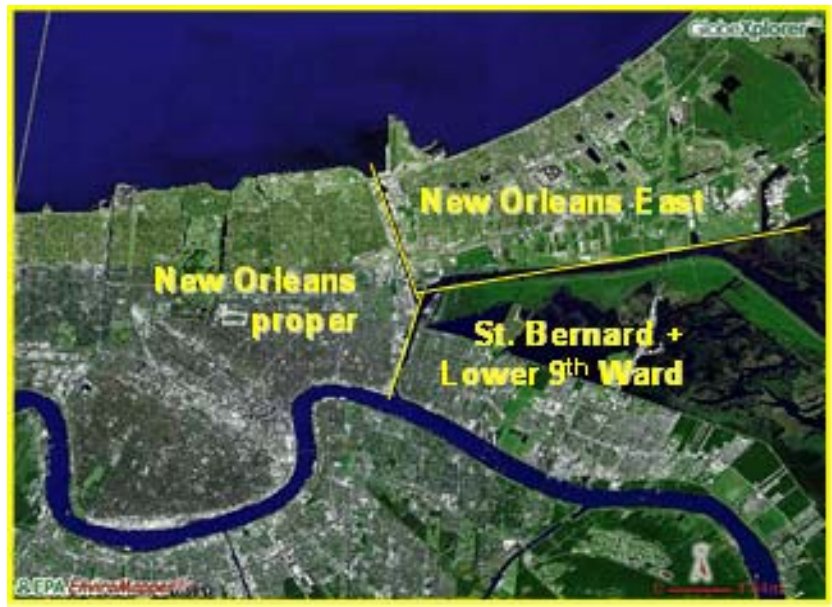

Figure 2: Map of New Orleans and neighboring areas showing the partitioning of the pump-out. Flood waters from New Orleans proper and New Orleans East were largely pumped into Lake Pontchartrain. Flood water from St. Bernard Parish and the Lower Ninth Ward of New Orleans were largely pumped into Violet Marsh.

The Corps of Engineers began to pump out the floodwater, and the final floodwater was declared pumped out on October 11, 2005. Many of the normal pumps that operate to drain the New Orleans area failed due to the effects of Katrina and the aftermath. Only Pump Stations \#1 and \#6 operated in the aftermath to drain the flood from the Lower Ninth Ward and Chalmette polder, pumping over the levee into the marsh beyond (Fig 3). Bayou Bienvenue winds through this marsh from the north near the municipal sewage treatment plant. This Violet Marsh west of the Mississippi River Gulf Outlet is accessed primarily by the Violet Canal to the south. ERDC scientists collected samples of sediment cores in Violet Marsh, analyzed for viable indicator bacteria and fecal sterols, and modeled the fate and transport of the fecal contaminants in order to assess the impacts of pumping contaminated water and sediment into this ecosystem near New Orleans.

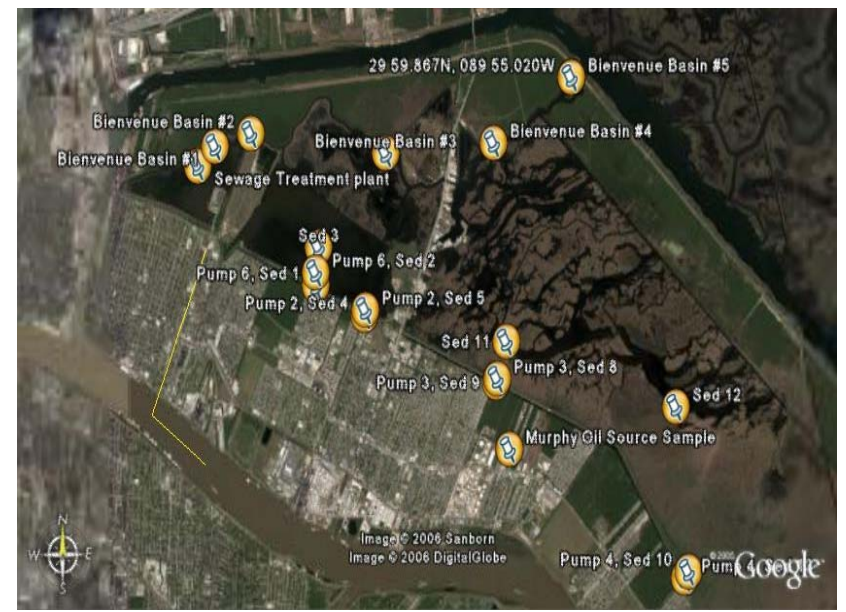

Figure 3: Map illustrating the sediment core locations with respect to the sewage treatment plant and stations that pumped flood water over the levee and into Violet Marsh. The GPS coordinates for the core locations are given in Table 1.

This study focused on Violet Marsh which received the water that was pumped from the Lower Ninth Ward and Chalmette. The main New Orleans sewage treatment plant is located there just east of the Industrial Canal and discharges into Bayou Bienvenue. This sewage treatment plant was flooded, damaged, and inoperable for weeks. The floodwater provided a nearly steady-state source of contamination to nearby ecosystems. The U.S. EPA and the LADEQ conducted extensive measurement operations throughout the flooded urbanized New Orleans area from September through December 2005. Louisiana State University [2, 24] and Texas Tech University [3] led independent sampling expeditions in flooded New Orleans, principally in parts of New Orleans proper. However, there is a lack of corresponding published data from Violet Marsh.

\section{Materials and Methods}

\section{Sediment Sampling}

ERDC scientists conducted a sampling trip 14-16 February 2006 to Violet Marsh outside the polder of the Lower Ninth Ward and the Chalmette area, using an airboat to access the Marsh. Sediment core sample locations were selected in an attempt to identify sources of fecal contamination and to assess the distribution of fecal contamination out into Violet Marsh. Sediment cores were collected from canals conducting water from the Lower 
Ninth Ward to the large stationary pumps that pumped the water over the levees, and from both the immediate influent and immediate effluent of the pumps that could have transported contaminants from these two sources into Violet Marsh. Sediment core samples were also collected at various distances from these pumps out into Violet Marsh to determine the range of transport of these contaminants into the Marsh. The GPS coordinates and sample designations of these sites are given in Table 1.

Sediment cores were obtained in sterilized acrylic sleeves using a stainless steel coring device of 4.0 inches inside diameter, and 12 in. length. Cross contamination was minimized by use of an $80 \%$ ethyl alcohol solution. The sealed samples were shipped on ice for analysis. In the laboratory the first $5 \mathrm{~cm}$ were aseptically removed from the top of each core and homogenized with a sterile spatula. Separately the lowest $5 \mathrm{~cm}$ were aseptically removed from the bottom of each core and homogenized. Portions of this homogenized sediment were frozen and aliquots set aside for the various physical, chemical and microbiological analyses. Dry weights were determined by drying an aliquot in the hood in ambient air for one day.

\section{Bacterial Indicators of Pathogens in Sewage}

Microbiological analyses for total coliform (SM 9222D), fecal coliform (SM 9222-D) and fecal streptococci (SM 9230-C) were performed on sediment samples using standard microbiological methods [25].

Table 1: Description of the sediment core locations in and around Violet Marsh

\begin{tabular}{|c|c|c|c|}
\hline Sewage Plant & 29.984166 & -90.001866 & Northwest of treatment plant in marsh \\
\hline Murphy Oil Site & 29.940866 & -89.931083 & $\begin{array}{l}\text { Munster Ln, North of Judge Perez, intersection of drainage canal } \\
\text { running N.W. }\end{array}$ \\
\hline Pump 2 Sed 5 & 29.962183 & -89.963783 & After pump \#2 \\
\hline Pump 3 Sed 8 & 29.951633 & -89.933833 & After pump \#3 \\
\hline Pump 3 Sed 9 & 29.951050 & -89.934100 & Before pump \#3 \\
\hline Pump 6 Sed 1 & 29.965925 & -89.975072 & Before pump \#6 \\
\hline Pump 6 Sed 2 & 29.967916 & -89.975088 & After pump \#6 \\
\hline Sed 3 & 29.971766 & -89.974433 & Due north of pump $\# 6$, middle of marsh \\
\hline Sed 11 & 29.957350 & -89.931783 & NNE of pump \#3, middle of marsh \\
\hline Sed 12 & 29.947333 & -89.893266 & Due north of pump \#4 middle of marsh \\
\hline Bienvenue Basin 1 & 29.987200 & -89.997950 & Adjacent to treatment plant aerator within discharge canal \\
\hline
\end{tabular}


Fecal Sterol Analyses

Fecal sterols were extracted from sediment samples using the methods described in Ringelberg et al. [26]. Sterol standards were purchased from Sigma-Aldrich Co. (coprostanol, 5ß-cholestan-3ß-ol; epicoprostanol, 5ßcholestan-3-ol; $\beta$-sitosterol, 24-ethylcholest-5-en-3ß-ol; stigmastanol, 24-ethyl-5 -cholestan-3ß-ol) and Applied Science Labs, State College, PA (coprostanone, 5Bcholestanone; cholesterol, cholest-5-en-3ß-ol; campesterol, 24-methylcholest-5-en-3ß-ol). A known amount of deuterated pyrene in methanol was mixed into 11 gram aliquots of the wet sediment to serve as a recovery standard. A mixture of dichloromethane:methanol:water $\quad(1: 2: 0.8, \quad \mathrm{v}: \mathrm{v}: \mathrm{v})$ was added to the sample. The sediment sample was then extracted for $1 \mathrm{hr}$ in an ultrasonic water bath at $10^{\circ} \mathrm{C}$, and then allowed to stand overnight. Equal volumes of dichloromethane (DCM) and water were added to break the liquid phases and the entire volume was centrifuged at $5000 \mathrm{rpm}$ for 10 minutes. The DCM phase containing the total extractable lipids was recovered using a glass pipette. The DCM was reduced in volume under a stream of dry nitrogen to approximately $100 \mu \mathrm{L}$ and then brought to a final volume of $2 \mathrm{~mL}$ with clean DCM. A portion $(100 \mu \mathrm{L})$ of this total lipid extract was derivatized using N-methyl-Ntrimethylsilyl-trifluoroacetamide (MSTFA) (Pierce Chemical, Woburn, MA) for fecal sterol analysis. The treatment with 25 $\mu \mathrm{L}$ MSTFA involved mixing in tightly capped tubes at $60^{\circ} \mathrm{C}$ for 1 hour as per the manufacturer's derivatization protocol.

Fecal sterols by GC/MS were determined using slight modifications to the standard method proposed by the Florida Department of Natural Resource Protection [27]. After TMS derivatization, fecal sterol samples were analyzed using a gas chromatograph equipped with a $60 \mathrm{~m} \times 0.25 \mathrm{~mm}$ (id) DB5MS capillary column $(0.1 \mu \mathrm{m}$ film thickness, J\&W Scientific, Folsom, CA) and a Mass Selective Detector (Hewlett Packard GC6890-5973). Peak identities were confirmed by comparing retention times and fragment ion masses (with electron impact ionization at $70 \mathrm{eV}$ ) to standards and the NIST MS database. Areas under the peaks were converted to concentrations, corrected to the efficiency of recovery of the deuterated pyrene and then normalized to the gram dry weight (gdw) of the wet aliquot extracted. The lower limit for quantization (LLQ) was measured as three times the standard deviation of matrix spikes. The lower limit of detection (LLD) was determined as three times the standard deviation of the noise in blanks. Both the LLQ and LLD for the fecal sterols were $0.1 \mathrm{nmol} / \mathrm{gdw}$.

Table 2: Levels of fecal indicator bacteria in the surface sediments of cores collected in and around Violet Marsh.

Table plate count results from Top of Soil Core

\begin{tabular}{lccccc}
\hline & & Total & Fecal & Fecal & 40 CFR 503 \\
\cline { 3 - 5 } Sample & Location & Conforms & Coliforms & Streptococci & BioSolid Res Std FecColif \\
\cline { 3 - 5 } & & CFU/gm & CFU/gm & CFU/gm & 1000 \\
\hline Bienvenue Basin 1 & TOP & 17,000 & $<1,000$ & $<1,000$ & - \\
Bienvenue Basin 2 & TOP & 12,000 & $<1,000$ & $<1,000$ & - \\
Bienvenue Basin 3 & TOP & $<1000$ & $<1,000$ & $<1,000$ & - \\
Bienvenue Basin 4 & TOP & $<1000$ & $<1,000$ & $<1,000$ & - \\
Bienvenue Basin 5 & TOP & 3,000 & $<1,000$ & $<1,000$ & - \\
Sewage Plant & TOP & 10,000 & $<1,000$ & $<1,000$ & $>$ \\
Murphy Oil Site & TOP & $1,600,000$ & 630,000 & 100 & $>$ \\
Pump 2 Sed4 & TOP & 57,000 & 14,000 & $<100$ & $>$ \\
Pump 2 Sed 5 & TOP & 133,000 & 25,000 & $<100$ & $>$ \\
Pump 3 Sed 8 & TOP & 84,000 & 5,000 & $<100$ & $>$ \\
Pump 3 Sed 9 & TOP & 630,000 & 70,000 & $<100$ & $>$ \\
Pump 4 Sed 10 & TOP & 77,000 & 10,000 & $<100$ & $>$ \\
Pump 4 Sed 13 & TOP & 128,000 & 15,000 & $<100$ & $>$ \\
Pump 6 Sed 1 & TOP & 30,000 & 8,000 & $<100$ & $>$ \\
Pump 6 Sed 2 & TOP & 65,000 & 2,000 & $<100$ & $>$ \\
Sed 11 & TOP & 33,000 & 3,000 & $<100$ & $>$ \\
Sed 12 & TOP & $>200000$ & 4,000 & $<1,000$ & \\
Sed 3 & TOP & 2,100 & 3,000 & $<100$ & \\
\hline Mean & & 192,073 & 65,750 & & \\
Standard Deviation & & 419,233 & 178,681 & & $>$ \\
Median & & 57,000 & 9,000 & & $>$ \\
\hline
\end{tabular}




\section{Results}

\section{Fecal Bacteria Indicator Culture Data}

Samples of sediments removed from the top $5 \mathrm{~cm}$ of each core were analyzed using the Standard Methods Most Probable Number Analyses of colony forming units (cfu) for total coliform, fecal coliform and fecal streptococci (Table 2).

The topmost portion of the collected sediment cores was expected to be the most recently deposited. Samples from the bottoms of these cores were not analyzed for fecal bacteria because these fecal bacteria are not thought to be able to survive for extended periods of time in sediments [28]. Only one sample from the top of the Murphy Oil drainage canal produced a reading that was above the lower detection limit of the fecal streptococci analysis. Fecal streptococci are the indicators currently recommended by the EPA for estuarine and marine waters, but no sediment quality standards are currently recommended. In contrast, all the total coliform analyses except those from the two outermost samples of Bayou Bienvenue produced moderate to high counts. The highest coliform values were not at the sewage treatment plant outfall but from the Murphy Oil drainage canal and locations indicating input from Chalmette into Violet Marsh. Fecal coliform counts exceeded the standard for biosolids set by 40 CFR 503 (1000 cfu/gdw) for all sample locations except the sewage treatment plant and all samples from the Bayou Bienvenue. The reason for relatively low total and fecal coliform bacteria in those locations was not clear but may be due inhibition of bacterial growth by co-occurring chemical contaminants and/or active coliphage activity (data not shown) in these chronically polluted areas.

\section{Fecal Sterol Data}

Coprostanol levels in the tops and bottoms of almost all cores collected indicated significant historic and recent fecal impacts on Violet Marsh (Table 3). These levels are comparable to those in heavily sewageimpacted coastal marshes in Barcelona, Spain and Havana, Cuba [22]. Analysis of the sterol content from the bottom of the cores provided some insights into the time dependence of the input of fecal matter into Violet Marsh. In the deeper earlier deposited sediments, the levels of coprostanol were highest in the two most western sampling stations in the Bayou Bienvenue; BB1 (61.2 nmol/gdw) and BB2 (87.8 nmol/gdw). Coprostanol levels rapidly decreased with distance to the east (BB3-5; 3.4-6.0 $\mathrm{nmol} / \mathrm{gdw})$. Together, these data suggested the sewage treatment plant (or other source in this area) constituted a major long-term source of fecal contamination but the distribution of this fecal material into Violet Marsh was rather limited. High to moderate levels of coprostanol were found in the bottom of the core taken closest to the sewage plant outfall (20.3 $\mathrm{nmol} / \mathrm{gdw}$ ) and pump stations \#2 (32.8 nmol/gdw), \#3 (12.6 $\mathrm{nmol} / \mathrm{gdw})$ and \#6 (8.0 nmol/gdw), indicating a long-term source of fecal contamination from these sources. It is important to note that almost all of the sediments analyzed exceeded the most lenient coprostanol sediment quality standard suggested (1 nmol/gdw), indicating that Violet Marsh has been chronically impacted by fecal material.

The coprostanol levels in sediment from the top of the cores also showed significant impacts from fecal contamination. The average level of coprostanol in the most recent sediment was higher $(20.2 \mathrm{nmol} / \mathrm{gdw})$ than that of the bottom sediment (16.9 nmol/gdw), which suggested recent increases fecal input. Additionally, the relative coprostanol distribution pattern in the most recent sediments was different from that observed from the analysis of core bottoms. The levels of coprostanol in the surface sediments of the eastern location in the Bayou Bienvenue $(\mathrm{BB} 1=28.3 \mathrm{nmol} / \mathrm{gdw} ; \mathrm{BB} 2=28.5 \mathrm{nmol} / \mathrm{gdw})$ were approximately half of those found in the sediments of the bottoms of these cores. This may reflect the lack of input due to the failure of the sewage treatment system that resulted from the flooding. In contrast, the surface sediments associated with pump stations \#2, \#3, \#4 and \#6 all contained higher levels of coprostanol than their respective core bottoms. This suggested that the flooding resulted in a greater fecal load to Violet Marsh than originated from Chalmette along the northern levee.

Ratios of the levels of various other sterols recovered from wetland sediment cores have been used as aids to data interpretation, particularly in highly productive systems where coprostanol levels were below $2 \mathrm{nmol} / \mathrm{gdw}$ and other sources of sterols had become significant. None of these sterol ratios were found particularly helpful in the context of gaining additional information from the data collected. The ratio of coprostanol / coprostanol+cholestanol did not change much with location or sediment depth, suggesting the relative importance of the different cholesterol reduction pathways did not change very much with time or location in the marsh. The ratio of epicoprostanol (formed from coprostanol in activated sludge) to coprostanol has been used as an indication of treated vs. non-treated sewage. Although this ratio fluctuated, it was difficult to rationalize these differences in terms of extent of sewage treatment.

\section{Discussion}

The pumping of floodwaters and entrained sediments provided a nearly steady-state source of contamination to nearby ecosystems for weeks. Although the measured concentrations in the Katrina storm water pump-out were reported to be similar to normal rainfall pump-out [2], the volume pumped out was much greater than normal: by 30 August $80 \%$ of New Orleans was flooded with up to $20 \mathrm{ft}$ of brackish water. Hurricane Rita caused several additional failures of the levees on 23-24 September. The last of the floodwaters were declared pumped out on October 11. However this enormous volume did not dilute the concentration of contaminants below that of normal rainfall; 
Table 3: Map illustrating the sediment core locations with respect to the sewage treatment plant and stations that pumped flood water over the levee and into Violet Marsh. The GPS coordinates for the core locations are given in Table 1.

\begin{tabular}{|c|c|c|c|c|c|c|c|c|c|}
\hline & & $A$ & $B$ & $C$ & $D$ & Ratio & Ratio & Ratio & Ratio \\
\hline Sample & Location & $\begin{array}{l}\text { Coprostanol } \\
n m o l / g m ~ d w\end{array}$ & $\begin{array}{c}\text { Epicoprostanol } \\
n m o l / g m d w\end{array}$ & $\begin{array}{l}\text { Cholesterol } \\
n m o l / g m d w\end{array}$ & $\begin{array}{l}\text { Cholestanol } \\
n m o l / g m d w\end{array}$ & $A / D$ & $B / A$ & $A / C$ & $A / A+D$ \\
\hline Bienvenue Basin 1 & Top & 28.3 & 1.6 & 43.5 & 3.8 & 7.37 & 0.06 & 0.65 & 0.88 \\
\hline Bienvenue Basin 2 & Top & 28.5 & 41.4 & 355.2 & 41.0 & 0.70 & 1.45 & 0.08 & 0.41 \\
\hline Bienvenue Basin 3 & Top & 9.2 & 0.8 & 43.6 & 7.9 & 1.16 & 0.08 & 0.21 & 0.54 \\
\hline Bienvenue Basin 4 & Top & 9.1 & 2.6 & 42.7 & 5.0 & 1.81 & 0.29 & 0.21 & 0.64 \\
\hline Bienvenue Basin 5 & Top & 4.2 & 0.4 & 110.9 & 5.1 & 0.82 & 0.10 & 0.04 & 0.45 \\
\hline Sewage Plant & Top & 27.3 & 18.1 & 29.2 & 6.5 & 4.20 & 0.66 & 0.93 & 0.81 \\
\hline Murphy Oil Site & Top & 20.8 & 0.6 & 17.2 & 1.3 & 15.58 & 0.03 & 1.21 & 0.94 \\
\hline Pump 2 Sed 4 & Top & 3.0 & 3.7 & 67.7 & 3.8 & 0.79 & 1.24 & 0.04 & 0.44 \\
\hline Pump 2 Sed 5 & Top & 61.3 & 4.6 & 344.7 & 30.3 & 2.02 & 0.07 & 0.18 & 0.67 \\
\hline Pump 3 Sed 8 & Top & 20.6 & 1.8 & 145.8 & 10.0 & 2.06 & 0.09 & 0.14 & 0.67 \\
\hline Pump 3 Sed 9 & Top & 39.1 & 2.2 & 90.0 & 9.1 & 4.31 & 0,06 & 0.44 & 0.81 \\
\hline Pump 4 Sed 10 & Top & 28.1 & 2.0 & 32.4 & 5.9 & 4.72 & 0,07 & 0.87 & 0.83 \\
\hline Pump 4 Sed 13 & Top & 13.4 & 1.0 & 68.6 & 6.3 & 2.11 & 0.08 & 0.20 & 0.68 \\
\hline Pump 6 Sed 1 & Top & 22.0 & 1.7 & 117.4 & 10.5 & 2.09 & 0.08 & 0.19 & 0.68 \\
\hline Pump 6 Sed 2 & Top & 9.5 & 0.8 & 44.3 & 6.8 & 1.39 & 0.08 & 0.21 & 0.58 \\
\hline Sed 11 & Top & 21.5 & 6.0 & 90.3 & 7.0 & 3.06 & 0.28 & 0.24 & 0.75 \\
\hline Sed 12 & Top & 4.3 & 0.7 & 40.6 & 7.3 & 0.58 & 0.17 & 0.10 & 0.37 \\
\hline Sed 3 & Top & 14.3 & 1.1 & 67.5 & 11.0 & 1.31 & 0.07 & 0.21 & 0.57 \\
\hline Mean & & 20.2 & 5.1 & 97.3 & 9.9 & 3.1 & 0.3 & 0.3 & 0.7 \\
\hline Standard Deviation & & 14.4 & 10.0 & 98.0 & 9.8 & 3.6 & 0.4 & 0.3 & 0.2 \\
\hline Median & & 20.7 & 1.8 & 67.6 & 6.9 & 2.0 & 0.1 & 0.2 & 0.7 \\
\hline Bienvenue Basin 1 & Bottom & 61.2 & 2.5 & 80.2 & 6.5 & 9.38 & 0.04 & 0.76 & 0.90 \\
\hline Bienvenue Basin 2 & Bottom & 87.8 & 4.6 & 115.4 & 11.3 & 7.78 & 0.05 & 0.76 & 0.89 \\
\hline Bienvenue Basin 3 & Bottom & 3.4 & 0.5 & 23.4 & 3.0 & 1.15 & 0.14 & 0.15 & 0.53 \\
\hline Bienvenue Basin 4 & Bottom & 6.0 & 0.5 & 33.2 & 7.0 & 0.86 & 0.09 & 0.18 & 0.46 \\
\hline Bienvenue Basin 5 & Bottom & 3.4 & 0.5 & 22.0 & 5.0 & 0.68 & 0.14 & 0.15 & 0.40 \\
\hline Sewaqe Plant & Bottom & 20.3 & 2.7 & 91.8 & 19.8 & 1.02 & 0.13 & 0.22 & 0.51 \\
\hline Murphy Oil Site & Bottom & 23.9 & 1.2 & 15.3 & 4.6 & 5.18 & 0.05 & 1.56 & 0.84 \\
\hline Pump 2 Sed 4 & Bottom & 8.1 & 0.7 & 84.5 & 4.8 & 1.67 & 0.09 & 0.10 & 0.63 \\
\hline Pump 2 Sed 5 & Bottom & 32.8 & 3.2 & 99.2 & 19.1 & 1.72 & 0.10 & 0.33 & 0.63 \\
\hline Pump 3 Sed 8 & Bottom & 0.9 & 0.1 & 4.9 & 0.4 & 2.16 & 0.08 & 0.19 & 0.68 \\
\hline Pump 3 Sed 9 & Bottom & 12.6 & 0.5 & 20.3 & 5.1 & 2.50 & 0.04 & 0.62 & 0.71 \\
\hline Pump 4 Sed 10 & Bottom & 0.0 & 0.0 & 2.7 & 0.9 & 0.00 & - & 0.00 & 0.00 \\
\hline Pump 4 Sed 13 & Bottom & 0.0 & 0.0 & 2,1 & 0.4 & 0.00 & - & 0.00 & 0.00 \\
\hline Pump 6 Sed 1 & Bottom & 5.0 & 0.5 & 24.0 & 3.5 & 1.41 & 0.10 & 0.21 & 0.59 \\
\hline Pump 6 Sed 2 & Bottom & 8.0 & 1.1 & 56.5 & 10.0 & 0.79 & 0.13 & 0.14 & 0.44 \\
\hline Sed 11 & Bottom & 14.2 & 1.4 & 84.5 & 12.3 & 1.15 & 0.10 & 0.17 & 0.54 \\
\hline Sed 12 & Bottom & 6.0 & 1.3 & 55.6 & 9.8 & 0.61 & 0.22 & 0.11 & 0.38 \\
\hline Sed 3 & Bottom & 11.2 & 1.1 & 63.3 & 18.4 & 0.61 & 0.10 & 0.18 & 0.38 \\
\hline Mean & & 16.9 & 1.2 & 48.8 & 7.9 & 2.1 & 0.1 & 0.3 & 0.5 \\
\hline Standard Deviation & & 23.1 & 1.2 & 36.8 & 6.2 & 2.6 & 0.0 & 0.4 & 0.3 \\
\hline Median & & 8.0 & 0.9 & 44.4 & 5.8 & 1.2 & 0.1 & 0.2 & 0.5 \\
\hline
\end{tabular}


a similar lack of source dilution was observed in a bayou in north Louisiana [29].

Tens of thousands of people who remained in the area were without basic necessities, and without a working sewage system. The main sewage treatment plant was submerged, damaged, and completely out of operation for several weeks. Much of the sewerage system was antiquated and permanently damaged from the flooding. Much raw sewage, particularly in the Lower Ninth Ward and Chalmette area polder, was still evident in surface waters in February 2006.

The criteria for bodily contact and accidental or incidental ingestion are developed in terms of groups of organisms found in fecal material and correlated to infectious human disease. The applicable legal standard is the primary contact recreational water quality criterion, which is $400 \mathrm{cfu} / 100 \mathrm{~mL}$ for fecal coliform bacteria [30, 31]. There are very few bacteriological sediment standards, and the large National Sediment Quality Survey [32] omits bacteriological data. However, the Federal biosolids rules are applicable to transported sediments which have been impacted by sewage sludge. The biosolids residential standard (40 CFR 503.32) for fecal coliform bacteria is $1000 \mathrm{cfu} / \mathrm{g}$.

According to the National Response Plan the EPA and Centers for Disease Control and Prevention (CDC) are primarily responsible for management of infectious agents in the environment. Screening of New Orleans flood water and sediment samples frequently showed fecal coliform bacteria levels high above the regulatory levels of concern. As a result, health advisories due to infectious material in the flooded New Orleans areas were issued. The advisories were warranted. Assessment of the actual human health impacts due to infectious agents as a result of the flood is an ongoing process but of the 10,047 New Orleans patient visits during and immediately after the flooding for which information was available to the $\mathrm{CDC}$ [23] the most common were gastrointestinal, acute respiratory and skin infections attributable to contact with the floodwaters and sediments. In the context of human health it is important to point out that the high levels of fecal coliform bacteria revealed by the screening procedures did detect a human health risk due to infectious agents, that health advisories were issued and that some summaries of impacts of human infections have been recently published.

New Orleans proper and New Orleans East were pumped out into Lake Pontchartrain. The impact on Lake Pontchartrain appeared to have been minimized by the large lake volume and currents [33]. In contrast, the dilution factor which probably mitigated much of the potential environmental impact on Lake Pontchartrain was much less a factor on Violet Marsh. Much of the Violet Marsh is confined by levees and this confined marsh received a great volume of material that was pumped out of the Lower Ninth Ward and the Chalmette. The level of chronic, long-term fecal contamination of Violet Marsh is similar to other urban sewage-impacted coastal wetlands areas and is well above suggested sediment quality criteria. The pump-out of the Lower Ninth Ward and Chalmette increased the mean concentration levels of fecal sterols above this already high background. However, additional analyses are required to remove uncertainty due to assumptions we made and the minimal statistical design of our Violet Marsh survey, and to quantify these impacts.

Acknowledgements: This work was supported by the U.S. Army Corps of Engineers through the Interagency Performance Evaluation Task Force.

\section{References}

1. U.S. Environmental Protection Agency. U.S. EPA Hurricane Response 2005. U.S. Environmental Protection Agency: Washington, DC, 2005. http://www.epa.gov/katrina/index.html.

2. Pardue, J. H.; Moe, W. M.; McInnis, D.; Thibodeaux, L. J.; Valsaraj, K. T.; Maciasz, E.; VanHeerden, I.; Korevec, N.; Yuan, Q. Z. Chemical and microbiological parameters in New Orleans floodwater following Hurricane Katrina. Environmental Science \& Technology, 2005, 39, 8591-8599.

3. Presley, S. M.; Rainwater, T. R.; Austin, G. P.; Platt, S. G.; Zak, J. C.; Cobb, G. P.; Marsland, E. J.; Tian, K.; Zhang, B.; Anderson, T. A.; Cox, S. B.; Abel, M. T.; Leftwich, B. D.; Huddleston, J. R.; Jeter, R. M.; Kendall, R. J.: Assessment of pathogens and toxicants in New Orleans, LA following Hurricane Katrina. Environmental Science \& Technology, 2006, 40, 468-474.

4. Interagency Performance Evaluation Task Force. Performance Evaluation of the New Orleans and Southeast Louisiana Hurricane Protection System. U.S. Army Corps of Engineers: Vicksburg, MS, 2006. https://ipet.wes.army.mil/

5. U.S. Environmental Protection Agency. U.S. EPA Surface Water Treatment Rule. National Primary Drinking Water Regulations. Code of Federal Regulations, Title 40, Part 141-142. U.S. Environmental Protection Agency: Washington, DC, 2002.

6. National Research Council. Indicators of waterborne pathogens. The National Academies Press: Washington, DC, 2004.

7. U.S. Environmental Protection Agency. Standardized analytical methods for use during homeland security events. U.S. Environmental Protection Agency: Washington, DC, 2004.

8. International Life Sciences Institute. Revised framework for microbial risk assessment. International Life Sciences Institute: Washington, DC, 2000.

9. Isobe, K. O.; Tarao, M.; Chiem, N. H.; Minh, L. Y.; Takada, H.: Effect of environmental factors on the relationship between concentrations of coprostanol and fecal indicator bacteria in tropical (Mekong Delta) and temperate (Tokyo) freshwaters. Applied and Environmental Microbiology, 2004, 70(2), 814-821.

10. Jin, G.; Englande, A. J.; Bradford, H.; Jeng, H.: Comparison of E. coli, enterococci, and fecal coliform 
as indicators for brackish water quality assessment. Water Environment Research, 2004, 76(3), 245-255.

11. Walker, R. W.; Wun, C; Litsky, W.: Coprostanol as an indicator of fecal pollution. CRC Critical Reviews in Environmental Control, 1982, 12, 91-112.

12. Nichols, P. D.; Leeming, R.; Rayner, M. S.; Latham, V.: Use of capillary gas chromatography for measuring fecal-derived sterols application to stormwater, the sea-surface microlayer, beach greases, regional studies, and distinguishing algal blooms and human and non-human sources of sewage pollution. Journal of Chromatography A. 1996, 733(1-2), 497-509.

13. Eneroth, P; Hellström, K; Ryhage, R.: Identification and quantification of neutral fecal steroids by gasliquid chromatography and mass spectrometry: studies of human excretion during two dietary regimens. Journal of Lipid Research, 1964, 5, 245-262.

14. Murtaugh, J. J.; Bunch, R. L.: Sterol as a measure of fecal pollution. J. Water Pollut. Control Fed. 1967, 39, 404-409.

15. Ogura, K.: Fate of coprostanol, an index of fecal pollution, in Tokyo Bay. Geochemistry, 1983, 17, 68-75.

16. Takada, H.; Farrington, J. W.; Bothner, M. H.; Johnson, C. G.; Tripp, B. W.: Transport of sludgederived organic pollutants to deep sea sediments at deep water dump site 106. Environmental Science \& Technology, 1994, 28, 1062-1072.

17. Nishimura, M.; Koyama, T.: The occurrence of stanols in various living organisms and the behaviour of sterols in contemporary sediments. Geochimica et Cosmochimica Acta, 1977, 41, 379-385.

18. Arscott, D. B.; Aufdenkampe, A. K.; Bott, T. L.; Dow, C. L.; Jackson, J. K.; Kaplan, L. A.; Newbold, J. D.; Sweeney, B. W.: Water quality monitoring in the source water areas for New York City: An integrative watershed approach. Stroud Water Research Center: Avondale, PA, 2004.

19. Kirchmer, C. J.: $5 \beta$-Cholestan-3 $\beta$-ol: an indicator of fecal pollution. Ph.D. thesis. University of Florida: Gainesville, FL, 1971.

20. Dutka, B. J.; Chau, A. S. Y.; Coburn, J.: Relationship between bacterial indicators of water pollution and fecal sterols. Water Res., 1974, 8, 1047-1055.

21. Leeming, R.; Coleman, R.: Bayside drains faecal origins study: Sterol/bacterial sampling 1999-2000. CSIRO Marine Research Report No. FPP- 02. Commonwealth Scientific and Industrial Research Organisation: Clayton, Victoria, Australia, 2000.

22. Grimalt, J. O.; Fernández, P.; Bayona, J. M.; Albaigés, J.: Assessment of fecal sterols and ketones as indicators of urban sewage inputs to coastal waters. Environmental Science \& Technology, 1990, 24(3), 357-363.
23. Centers for Disease Control and Prevention. Surveillance for Illness and Injury after Hurricane Katrina--Three Counties, Mississippi, September 5October 11, 2005. Journal of the American Medical Association, 2006, 295, 1994-1996.

24. Hou, A.; Laws, E. A.; Gambrell, R. P.; Bae, H-S.; Tan, M.; Delaune, R. D.; Li, Y.; Roberts, H.: Pathogen Indicator Microbes and Heavy Metals in Lake Pontchartrain following Hurricane Katrina. Environmental Science \& Technology, 2006, 40, 5904-5910.

25. Eaton, E. D.; Clesceri, L. S.; Rice, E. W.; Greenberg, A. E.; Franson, M. A. H. (eds.): Standard Methods for the Examination of Water and Wastewater, 21st Ed. American Public Health Association, American Water Works Association, Water Environment Federation: Washington, DC, 2005.

26. Ringelberg, D. B., Talley, J.; Perkins, E.; Bouwer, E.; Luthy, R.; Fredrickson, H. L.: Succession of phenotypic, genotypic and metabolic community characteristics during in vitro bioslurry treatment of PAH-contaminated sediments. Applied and Environmental Microbiology, 2001, 67(4), 1542-1550.

27. Gomez, D.; Page, R. W.; Holsing, N.; Gassman, N.; Riley, G. F.: Implementation of a Chemical Method for Differentiating Human and Animal Fecal Impacts in Surface Waters and Sediments. Florida Department of Natural Resource Protection: Fort Lauderdale, FL, 1998.

28. Burton, G. A.; Gunnison, D.; Lanza, G. R.: Survival of pathogenic bacteria in various freshwater sediments. Applied and Environmental Microbiology. 1987, 53(4), 633-638.

29. Hill, D. D.; Owens, W. E.; Tchounwou, P. B.: The Impact of Rainfall on Fecal Coliform Bacteria in Bayou Dorcheat (North Louisiana). Int. J. Environ. Res. Public Health, 2006, 3(1), 114-117.

30. U.S. Environmental Protection Agency. Bacterial water quality standards for recreational waters (freshwater and marine waters). U.S. Environmental Protection Agency: Washington, DC, 2003.

31. Louisiana Department of Environmental Quality. Posthurricane water quality assessments: Katrina monitoring. Louisiana Department of Environmental Quality: Baton Rouge, LA, 2005.

32. U.S. Environmental Protection Agency. The incidence and severity of sediment contamination in surface waters of the United States: National Sediment Quality Survey. U.S. Environmental Protection Agency: Washington, DC, 2004.

33. Dortch, M. S.; Zakikhani, M.; Kim, S-C.: Contaminant Fate/Transport Modeling for Environmental Consequences of IPET Task 9. ERDC/EL TR-06-9. U.S. Army Engineer Research and Development Center: Vicksburg, MS, 2006. 